\title{
Video Article \\ Isolation of Mouse Epidermal Keratinocytes and Their In Vitro Clonogenic Culture
}

\author{
Rebecca J. Morris ${ }^{1}$, Nyssa Readio ${ }^{1}$, Kelsey Boland ${ }^{1}$, Kelly Johnson ${ }^{1}$, Sonali Lad ${ }^{1}$, Anupama Singh ${ }^{1}$, Ashok Singh ${ }^{1}$, Stephanie Holtorf ${ }^{1}$, \\ Samantha Skaar ${ }^{1}$ \\ ${ }^{1}$ Hormel Institute, University of Minnesota
}

Correspondence to: Rebecca J. Morris at morri877@umn.edu

URL: https://www.jove.com/video/58701

DOI: doi:10.3791/58701

Keywords: Biology, Issue 150, epidermal keratinocytes, cell culture, adult mouse epidermis, clonal culture, keratinocyte stem cells, 3 T3 fibroblast

Date Published: 8/10/2019

Citation: Morris, R.J., Readio, N., Boland, K., Johnson, K., Lad, S., Singh, A., Singh, A., Holtorf, S., Skaar, S. Isolation of Mouse Epidermal Keratinocytes and Their In Vitro Clonogenic Culture. J. Vis. Exp. (150), e58701, doi:10.3791/58701 (2019).

\section{Abstract}

The protocol described here is a reliable method of harvesting primary keratinocytes from adult female mice (54 \pm 2 days old) yielding approximately $30 \times 10^{6}$ viable cells per mouse. Primary adult mouse keratinocytes are harvested from the dorsal skin of female mice. Male mice ( 6 weeks old) can be used for keratinocyte harvesting depending on the requirements of the experiment. Euthanized mice are shaved and sterilized with serial washes in povidone iodine and ethanol solutions ( $70 \%$ alcohol). After disinfecting the mice, the dorsal skin is removed and the subcutaneous fat and muscle are removed with a scalpel and discarded. The skins are cut into small pieces and treated with a mild, low temperature trypsinization to detach the lower dermis from the epidermis. The scraped epidermises are stirred at low speed, filtered to remove the hairs, counted, and re-suspended in culture medium. This method provides an excellent single cell suspension of highly culturable cells for many downstream applications.

\section{Video Link}

The video component of this article can be found at https://www.jove.com/video/58701/

\section{Introduction}

Mammalian skin covers the entire body and serves a multitude of functions (e.g., a primary physical barrier, temperature regulation, and moisture retention). Over the last five decades, basic research on mouse skin has yielded new information on the structure and function of the skin. The mouse skin model has greatly helped understanding of the basic biology behind the complex molecular mechanisms of chemical or ultraviolet radiation-induced carcinogenesis. These mouse skin models provided a significant contribution towards understanding of human skin diseases and their mitigation. To explore further molecular dissection of the primary keratinocytes in hair follicle developmental biology, stem cell research, carcinogenesis, and genetic exploration of epidermis, it is frequently desirable to isolate and culture primary epithelial keratinocytes from mice skin to use in parallel with in vivo experiments. The motivating factor in developing this method was the need for an in vitro assay for clonogenic epidermal and hair follicle stem cells ${ }^{1,2}$. There was also an urgent need for single cell suspensions of epidermal cells suitable for clonogenic assays $^{3}$, fluorescence activated cell sorting, and flow cytometry ${ }^{3,4}$. The advantages of this method are a robust harvest increase an order of magnitude over other methods $s^{5,6}$, inclusion of the epithelial portion of the hair follicles, and the high culturability of the harvested cells. In the 1980s, there were no known methods that could meet these requirements. In subsequent years, this method was refined to increase cell yield. The principal limitation of this method would be masking of some trypsin sensitive antibodies that would compromise immunoreactivity ${ }^{6}$.

The mice received husbandry according to the Specific Pathogen Free guidelines. One to five female mice $54 \pm 2$ days of age were obtained. In older mice, the viability of keratinocytes will be reduced due to anagen phase (growth) of the hair cycle. Also, the process of trypsinization is more difficult compared to young mice. The harvesting procedure has been successfully optimized for the thinner skin of female mice compared to male. Male mice are generally not used for keratinocyte harvests as they have a tendency to fight with one another during housing and therefore may leave scratches or wounds on the skin.

\section{Protocol}

All vertebrate animal use protocols have been approved by the University of Minnesota Institutional Animal Care and Use Committee in accordance with recommended NIH and government guidelines.

\section{Feeder Layer Initialization and Subculturing}

1. Thaw one cell vial containing frozen Swiss mouse $3 \mathrm{~T} 3$ from the liquid nitrogen tank by placing the vial in a $37^{\circ} \mathrm{C}$ water bath for $1-2$ min. The number of cells in the vial is approximately $1 \times 10^{6}$. 
2. Remove the 3 T 3 cell vial when the final sliver of ice has melted. Wipe the tube with a $70 \%$ alcohol swab. Then, transfer the vial to a biosafety cabinet.

3. Transfer the cells slowly into a T-150 flask, and rinse the $3 T 3$ vial with $1 \mathrm{~mL}$ of CGM medium. Slowly add $30 \mathrm{~mL}$ of pre-warmed $3 T 3 \mathrm{Complete}$ Growth Medium (CGM) to the cells. Gently rock the flask to evenly spread the 3T3 fibroblast cells. Label the flask with cell line details, date, and passage number appropriately.

4. Incubate the cells at $37^{\circ} \mathrm{C}$ with $5 \% \mathrm{CO}_{2}$ and $95 \%$ humidity.

NOTE: According to the ATCC, the doubling time of Swiss mouse 3 T3 is $18 \mathrm{~h}$; when confluent (contact inhibited), the density is about 40,000 cells per $\mathrm{cm}^{2}$. We use a particular line of 3T3 within 10-15 passages after initialization. More rapid growth or the presence of spindle-shaped cells can occur at higher passages and is usually a sign that the 3T3 will not perform as well as feeder cells for adult mouse keratinocytes. If rapid growth occurs, it is better to initiate a new line from lower passage cells.

5. Change media after $24 \mathrm{~h}$ to remove dead cells and remaining DMSO (cryopreservation agent), and twice weekly thereafter. Allow cells to proliferate around $80 \%$ confluence and use T-150 flasks for culture initiation. Use T-225 flasks for subculture after initialization.

6. To subculture $3 \mathrm{~T} 3$ fibroblast cells, remove the flask from the cell culture incubator and wash twice with cold sterile PBS (1x) with gentamycin. Pipet $10 \mathrm{~mL}$ of pre-warmed $\left(37^{\circ} \mathrm{C}\right.$ water bath) trypsin solution $(0.25 \%)$ into each T-225 flask.

1. Place the flask on a warming plate for 3-8 min. Remove the flask and gently use palms to tap the walls of the flask to detach cells and confirm cell detachment under inverted microscope. Trypsin solution may appear cloudy with detached 3T3 cells.

7. Pipet the trypsin solution $3-4 x$ to wash the cell growth surface of the flask and transfer the trypsinized cell to $30 \mathrm{~mL}$ of $C G M$ in a $50 \mathrm{~mL}$ conical tube. Rewash the flask 3-5x with $10 \mathrm{~mL}$ of the CGM-trypsin-cell mixture from the $50 \mathrm{~mL}$ conical tube.

NOTE: The contents of two flask contents can be added to a $50 \mathrm{~mL}$ tube; if only one flask is used, then place $10 \mathrm{~mL}$ of trypsin/cells into 20 $\mathrm{mL}$ of $\mathrm{CGM}$ in a $50 \mathrm{~mL}$ tube.

8. Centrifuge the $50 \mathrm{~mL}$ conical tube at $160 \times g$ for $7 \mathrm{~min}$ at $4{ }^{\circ} \mathrm{C}$.

9. Now aspirate the supernatant and resuspend the cell pellet with $5 \mathrm{~mL}$ of CGM, pipetting gently $\sim 10 x$ to completely disrupt the cell pellet. Add $10 \mathrm{~mL}$ of CGM to bring the total volume of the $50 \mathrm{~mL}$ conical tube to $15 \mathrm{~mL}$.

1. Mix again $\sim 10 x$ and place $5 \mathrm{~mL}$ of the cell suspension into 3 separate T-150 flasks. The subculture ratio is $1: 3$ in T-225 flasks or $1: 4$ in T-150 flasks. Add $30 \mathrm{~mL}$ of pre-warmed 3T3 CGM to each of the flasks.

10. Label the flask with the cell line name, the date of cell seeding, and the passage number.

11. To freeze down 3 T3 cells following centrifugation in the subculture step, remove the $50 \mathrm{~mL}$ tube from the centrifuge and place on an ice bucket. Aspirate the supernatant and resuspend the cell pellet with $1 \mathrm{~mL}$ of $5 \%$ DMSO-DMEM mixture (see Table 1) for each flask harvested.

12. Place $1 \mathrm{~mL}$ of DMSO-DMEM mixture with cell suspension into each cryovial (one cryovial per $3 T 3$ flask harvested). Label the vial with the passage number, the cell line name (3T3), and the date that the cells were frozen.

13. Place these $3 T 3$ cell vials into cell freezer jar (see Table of Materials) and transfer to $-70{ }^{\circ} \mathrm{C}$ freezer for $>5 \mathrm{~h}$. Careful remove and transfer the vials from the cell freezer jar and place in a liquid nitrogen storage tank for long-term storage until next use. Enter information about the cell line name, the location in tank and the date in the laboratory liquid nitrogen inventory sheet.

\section{Preparation of 3T3 Feeder Layer for X-ray Irradiation and Seeding}

1. Prepare $3 T 3$ cells one week before their irradiation and allow them to grow $\sim 100 \%$ confluence. The 3 T 3 cells are typically within the passages of 120 to 130 .

2. For successful clonogenic assays of primary keratinocytes, before seeding $3 T 3$ cells, surface coat the $60 \mathrm{~mm}$ Petri dishes with a collagen.

1. Pipet around $2-3 \mathrm{~mL}$ of the collagen-coating solution into $60 \mathrm{~mm}$ Petri dishes to coat the bottom surface and remove the excess collagen-coating liquid (see Table 1). Transfer the Petri dishes to a $37{ }^{\circ} \mathrm{C}$ incubator with $5 \% \mathrm{CO}_{2}$ for a minimum of $1 \mathrm{~h}$. Do not let the dishes dry in incubator.

3. X-ray irradiation step: Follow steps 1.4-1.6. Use $50 \mathrm{~mL}$ of fresh CGM to re-suspend the cell pellet, close the conical tube and seal with paraffin sealing film. To avoid any contamination, use plastic bags to double bag the paraffin-sealed cell containing tube and place on ice. A mitomycin based alternative feeder layer can be used for keratinocyte culture ${ }^{7}$

4. Irradiate fibroblast $3 \mathrm{~T} 3$ cells in the $\mathbf{5 0} \mathrm{mL}$ conical tube with a 5,000 rads (50 Cgy) dose with a biological $\mathrm{x}$-ray machine. Irradiate these cells along with the CGM media.

1. Following X-ray irradiation, centrifuge cells at $160 \mathrm{xg}$ for $7 \mathrm{~min}$ at $4{ }^{\circ} \mathrm{C}$. Aspirate the supernatant media and gently resuspend cell pellet with $5 \mathrm{~mL}$ of CGM triturating gently $\sim 10 \mathrm{x}$. Now bring the final volume to $30 \mathrm{~mL}$ with additional $25 \mathrm{~mL}$ of medium and triturate $10 \mathrm{x}$. These triturating steps are crucial for uniform $3 \mathrm{~T} 3$ fibroblast layer for clonogenicity assay.

5. Viable Cell counting: Count the keratinocytes using a regular glass hemocytometer. Take approximately $0.5 \mathrm{~mL}$ of the cells and place into a $1.5 \mathrm{~mL}$ tube. Remove $200 \mu \mathrm{L}$ of cell mixture and add an equal volume of $0.4 \%$ Trypan blue solution and mixture 3-4x. Transfer cells with a hemocytometer and count all nucleated cells (small gold and pink cells) as viable cells. Calculate the final concentration of viable gold cells.

6. Pipette $1 \times 10^{6} 3 \mathrm{~T} 3$ cells (a minimum of $7 \times 10^{5}$ ) cells may be used) into $60 \mathrm{~mm}$ collagen-coated Petri dishes (step 2.2 ) and gently add $4 \mathrm{~mL}$ of modified high-calcium Williams E media (see Table 1). Allow freshly seeded $3 T 3$ cells to attach for $24 \mathrm{~h}$. On the next day, harvest the fresh primary keratinocyte and seed them on top of attached 3T3 fibroblast layer for clonogenic assay as indicated below.

\section{Primary Keratinocyte Harvesting and Seeding}

1. Euthanize four to five adult female mice via $\mathrm{CO}_{2}$ inhalation according to approved animal facility/IACUC standards. However, this protocol may also be used for single female/male mice.

1. Clip approximately $9 \mathrm{~cm}^{2}$ of the dorsal fur with an electric animal clipper and place all clipped mice into a $500 \mathrm{~mL}$ jar with enough povidone iodine antiseptic solution (not scrub) to cover them for 1-2 min. Shake the jar well to evenly coat the antiseptic solution over the mice. 
2. Pour off the solution and rinse with clean water until the liquid runs clear. Repeat the same antiseptic wash followed by a water rinse. After the antiseptic wash with iodine solution, soak all the mice in $70 \%$ ethanol for $5-10 \mathrm{~min}$.

NOTE: Mice with light fur (e.g., BALB/c) will retain a slight yellowish color from the antiseptic iodine washes, while darker mice (e.g., C57BL/6) will not. Notably, cell viability or culture growth is not affected due to the yellow color.

2. Carefully remove the clipped dorsal skin using thumb forceps and scissors in a laminar flow hood. Place the excised dorsal skin in conical tube filled with PBS/2x gentamycin. Avoid using ventral side skin to prevent mammary cell contamination in culture.

3. Using autoclaved forceps and a scalpel, place one dorsal skin at a time hairy side down onto a thin Petri dish. Start scraping all subcutaneous tissue including fat from the ventral side of the skin tissue until it is semi-translucent. Try to remove maximum traces of subcutaneous tissue without tearing the skin (hair follicle part). Also, do not scrape for a long time and avoid skin drying.

1. Keep scraped skin in PBS solution until all other remaining skins are processed. Using a scalpel, slice skins into $0.5 \mathrm{~cm} \times 1-1.5 \mathrm{~cm}$ strips and place the hairy side up onto a sterile Petri dish.

4. Carefully pipette $20 \mathrm{~mL}$ of PBS/2x Gentamicin solution mixed with trypsin $(0.25 \%)$ into a $100 \mathrm{~mm} \times 20 \mathrm{~mm}$ plastic Petri dish. Using sterile forceps, transfer the skins and float them hairy side up on the surface of trypsin solution for $2 \mathrm{~h}$ in a $32{ }^{\circ} \mathrm{C}$ incubator. NOTE: Trypsinization time and temperature are crucial for good yield of highly culturable primary keratinocytes. Although other methods may provide good yields of viable cells, the culturability of the keratinocytes has been less satisfactory.

1. During this $2 \mathrm{~h}$ incubation time, coat dishes with collagen coating and place them at $37^{\circ} \mathrm{C}$ for $1 \mathrm{~h}$ (see step 3.1.2). For clonogenic assays, the $60 \mathrm{~mm}$ Petri dishes have already been coated $24 \mathrm{~h}$ prior to keratinocyte harvesting to allow the irradiated 3T3 feeder layer to attach to bottom and spread evenly.

NOTE: Coating of culture dishes for clonogenic culture is very important for proper attachment, colony formation, and ultimate growth/ proliferation of mice epidermal keratinocytes.

5. Epidermal scraping step: Arrange a sterile plastic square Petri dish and create a surface at a $30^{\circ}$ incline for proper epidermal scraping with $15 \mathrm{~mL}$ of harvesting medium (see Table 1). Carefully remove a floating skin strip from the trypsin solution with curved forceps. With a new scalpel blade, scrape off the epidermis and hairs into the medium.

1. Do not use excessive force, but use sufficient force to scrape the epidermis, or it will affect the cell viability.

2. During epidermis scraping, keep the blade perpendicular to the skin piece. If the blade is angled toward the motion of the blade, there are more chances of skin tearing. If the blade is angled away from the blade movement, there are more chances of insufficient epidermis removal.

6. Carefully pour the harvesting medium containing scraped epidermal cells into a sterile $60 \mathrm{~mL}$ jar (autoclavable and reusable) with a 1.5 inch magnetic stir bar. Rinse the Petri dish with additional harvesting medium to collect remaining epidermal cells and bring the final volume to $30 \mathrm{~mL}$. Use a magnetic stirrer and stir at $100 \mathrm{rpm}$ for $20 \mathrm{~min}$ at room temperature. This process will remove the trapped epidermal cells from hairs.

7. Place a sterile $\mathbf{7 0} \mu \mathrm{m}$ cell strainer on the top of a $\mathbf{5 0 ~ m L}$ conical tube. The cell strainer fits on top of a $\mathbf{5 0 ~ m L ~ c o n i c a l ~ t u b e . ~}$

1. Take the jar inside a biosafety hood. Remove the stir bar and pour the contents into strainer filter attached to a $50 \mathrm{~mL}$ conical tube. Strain out undesired hair and sheets of stratum corneum.

2. Press the hairs along with stratum corneum materials within the strainer and manipulate them to release the trapped hair cells. Use $5 \mathrm{~mL}$ of harvesting medium to allow remaining trapped cells to release and flow into the tube. Bring the total volume up to $50 \mathrm{~mL}$ in conical tube.

8. Cap the $50 \mathrm{~mL}$ conical tube with cell filtrate and centrifuge at $160 \times g$ for $7 \mathrm{~min}$ at $4{ }^{\circ} \mathrm{C}$. Next aspirate the supernatant and add $5 \mathrm{~mL}$ of harvesting medium. Resuspend the cell pellet by triturating gently $\sim 20 x$ with a $5 \mathrm{~mL}$ pipet.

1. At this step, keep the cells in an icebox to avoid any aggregation. Add $25 \mathrm{~mL}$ of harvesting medium and triturate again (20-25x).

2. To ensure an accurate keratinocyte count at this step, take $1 \mathrm{~mL}$ of cell suspension and add $19 \mathrm{~mL}$ harvesting medium. Now the cell dilution is $1: 20$ in $50 \mathrm{~mL}$ conical tube. If keratinocytes are harvested from a single mouse, adjust the volume of the cell suspension. Instead of $30 \mathrm{~mL}$, use $15 \mathrm{~mL}$ and make a 1:10 dilution for counting the cells.

9. Pipet $0.5 \mathrm{~mL}$ of diluted cells from the $50 \mathrm{~mL}$ conical tube (1:20 dilution) and transfer to a $1.5 \mathrm{~mL}$ autoclaved microcentrifuge tube. Remove $0.2 \mathrm{~mL}(200 \mu \mathrm{L})$ of cell mix to another $1.5 \mathrm{~mL}$ microcentrifuge tube and add an equal volume $(200 \mu \mathrm{L})$ of $0.4 \%$ Trypan blue solution. Gently mix this solution $3 x$ and transfer cells to a hemocytometer for counting nucleated keratinocytes.

1. Score all dark blue cells positive for Trypan blue as non-viable dead cells, and score small gold and pinkish cells as viable cells. The final keratinocyte yield per mouse should be around 30 million viable cells.

10. Centrifuge the original $50 \mathrm{~mL}$ conical tube (from step 3.8) for $7 \mathrm{~min}$ at $160 \times \mathrm{g}$ at $4{ }^{\circ} \mathrm{C}$. At this step, resuspend the cells in desired medium and make the required dilution for seeding cells.

1. For mass culture, seed 2 to 4 million viable gold cells in each $35 \mathrm{~mm}$ Petri dish in cell culture medium (KGM-type medium + supplements for monolayer cultures) (see Table 1). For a clonogenic (colony formation) assay, seed 1,000 cells per $60 \mathrm{~mm}$ Petri dish on X-ray irradiated Swiss mouse 3T3 feeder layers with collagen-coating and modified William's E medium with supplements and serum.

2. Use a total of 2 to $4 \mathrm{~mL}$ medium for $35 \mathrm{~mm}$ and $60 \mathrm{~mm}$ Petri dishes, respectively. Also, formulate DMEM and Williams $E$ medium procured from ATCC with reduced levels of sodium bicarbonate for use at $5 \% \mathrm{CO}_{2}$.

11. Grow the culture cells (mass or clonogenic) at $32{ }^{\circ} \mathrm{C}, 95 \%$ humidity with $5 \% \mathrm{CO}_{2}$. Change the media one day after initial seeding for mass culture, and then $3 x$ weekly thereafter. However, for clonal assays, the first medium change is 2 days after cell seeding and $3 x$ weekly thereafter.

12. For clonal culture, cultivate cells at two- and four-week intervals. After completion of clonal cultures (2 or 4 weeks), aspirate the medium. Fix the colonies in $10 \%$ buffered formalin overnight at room temperature and stain with $0.5 \%$ rhodamine $B$ in autoclave water for $1 \mathrm{~h}$. Then, remove the rhodamine B stain with a pipette from the edge of the dishes. 
1. Rinse the dishes in cold autoclaved water until the dishes run clear. Put the dishes inclined on the lid of the dishes and let them dry for final colony counting. Notably, when performing clonogenic culture assay, never pipet $<1 \mathrm{~mL}$ of cells. If cells are concentrated, serially dilute the cell concentration.

\section{Representative Results}

Typically, yields of epidermal keratinocytes per mouse ranging from $20 \times 10^{6}$ to $30 \times 10^{6}$ Trypan blue excluding cells are obtained ${ }^{8,9}$. The viability ranges from $80 \%-90 \%$. Typical seeding efficiencies are around $30 \%$ attachment at $24 \mathrm{~h}$. Colony formation on irradiated 3 T3 feeder layers is around 60 colonies per 1,000 viable cells seeded for C57BL/6 mice, and approximately 30 colonies per 1,000 cells for Swiss-type mice ${ }^{10,11}$. Typical results from colony formation assays are illustrated in Figure 1. The number of hair follicle stem cells is approximately $9 \% \mathrm{CD}^{2} 4^{+} / \mathrm{CD} 49 \mathrm{f}^{+}$ stem cells for C57BL/6 mice ${ }^{12}$. Typical results from flow cytometry are given in Figure 2.

Growth characteristics of four different media are illustrated in Figure 3. The media tested include KGM-gold, SFM, William's E medium, and Morris-2 (a reduced calcium medium developed in the Morris laboratory based on Williams E).

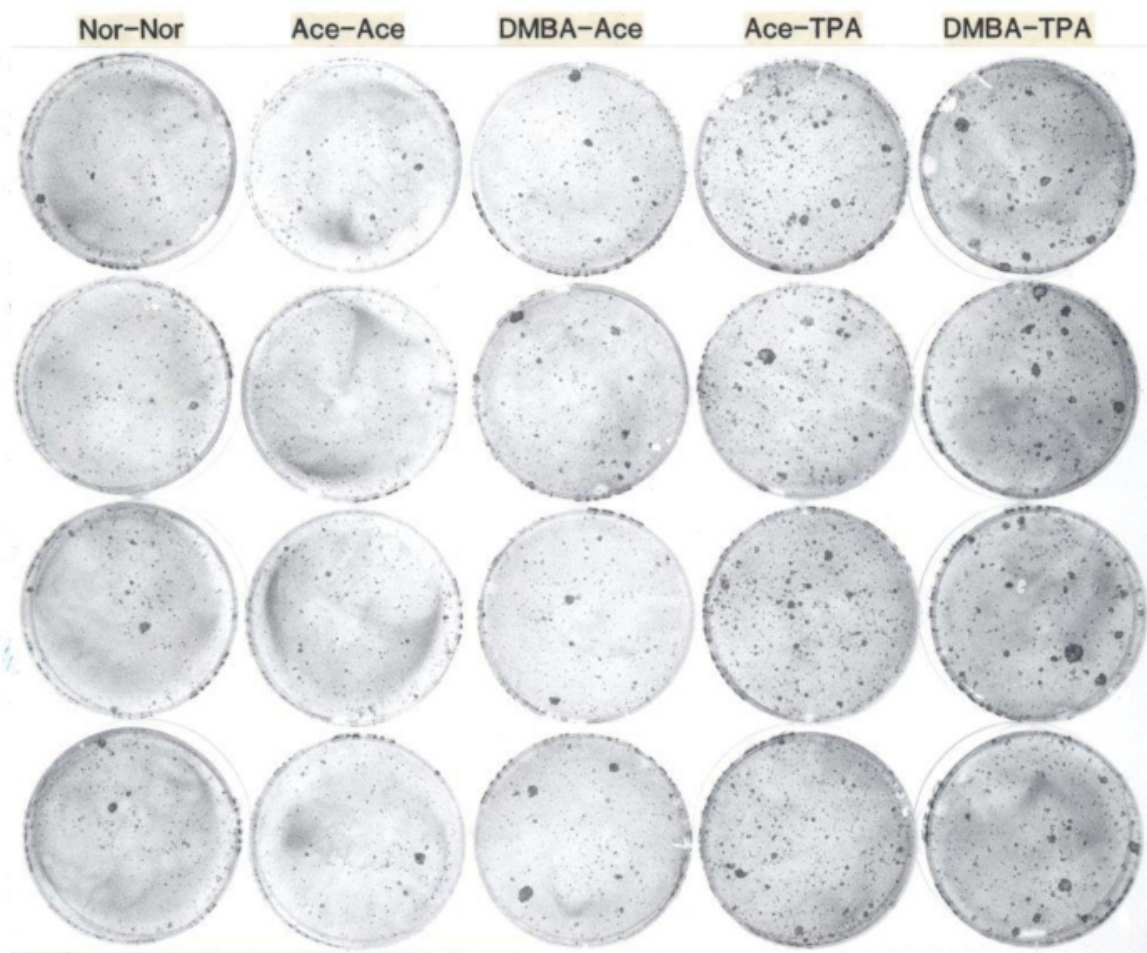

Figure 1: Representative examples from an assay for clonogenic keratinocytes from adult mice. This photograph demonstrates keratinocyte colony formation from CD-1 female mice 54 days of age treated topically with 1) no treatment, 2) acetone followed one week later by acetone twice weekly for two weeks, 3) DMBA followed one week later by acetone twice weekly for two weeks, 4) acetone followed one week later by TPA twice weekly for two weeks, and 5) DMBA followed one week later by TPA twice weekly for two weeks. After their in vivo treatments, keratinocytes were harvested and seeded at 1,000 cells per dish onto feeder layers of irradiated 3T3, and cultured for two weeks, after which the dishes were fixed with buffered formalin and stained with rhodamine B. The dishes in each column are replicates from each mouse treatment group. Note that the number of larger colonies increased upon treatment with DMBA, and the total number of colonies increased TPA treatment of the mice prior to keratinocyte harvest. Abbreviations: DMBA: 7,12-dimethylbenz[a]anthracene; TPA: 12-O-tetradecanoylphorbol-13-acetate. Please click here to view a larger version of this figure. 


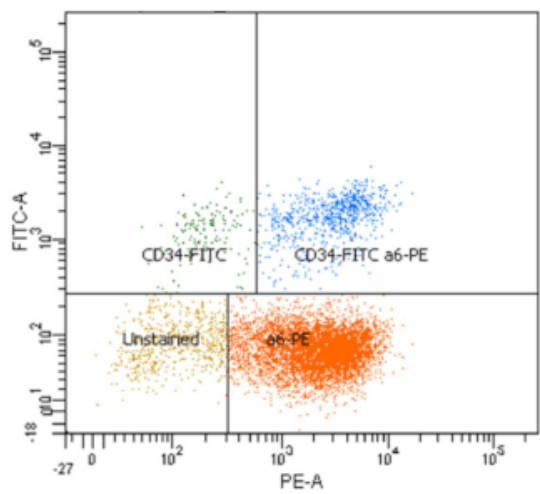

\section{Flow Cytometry of Hair Follicles Stem Cells from Adult Mice}

\begin{tabular}{|lrrr|}
\hline Tube: CD34-FITC a6-PE & & & \\
Population & \#Events & \%Parent & \%Total \\
All Events & 15,000 & 61.9 & 61.9 \\
\hline P1 & 9,285 & 6100.0 \\
Live Cells & 7,680 & 82.7 & 51.2 \\
CD34-FITC & 149 & 1.9 & 1.0 \\
CD34-FITC a6-PE & 747 & 9.7 & 5.0 \\
$\square$ Unstained & 588 & 7.7 & 3.9 \\
$\square$ a6-PE & 6,196 & 80.7 & 41.3 \\
\hline
\end{tabular}

Figure 2: Representative example of flow cytometry of hair follicle stem cells from adult mice. Briefly, the isolated primary keratinocytes were isolated from dorsal mice skin and filtered for cellular debris using cell filter. The isolated keratinocyte suspension was labeled with CD49f or a6-integrin (PE) and CD34 (FITC) antibodies along with live dead dye and other controls. FITC and PE isotype control antibodies (Rat IgG2akappa) were used for compensation purpose (see Table of Materials). Stem cells were selected by means of CD49f (PE channel), which recognized the external component of the hemi-desmosomes found on basal epidermal and hair follicle cells, and CD34 (FITC channel), which recognized the hair follicle stem cells (i.e., CD34-FITC ${ }^{+}$and $\mathrm{a6}-\mathrm{PE}^{+}$(upper right column, total $5 \%$ )). The right side column shows the different keratinocyte populations namely CD34-FITC only, CD34-FITC and a6-PE cells (double positive stem cell population), a6-PE only, and unstained cells. Note that there are two CD $34^{+}$stem cell populations as have been reported ${ }^{6,14}$. Please click here to view a larger version of this figure.

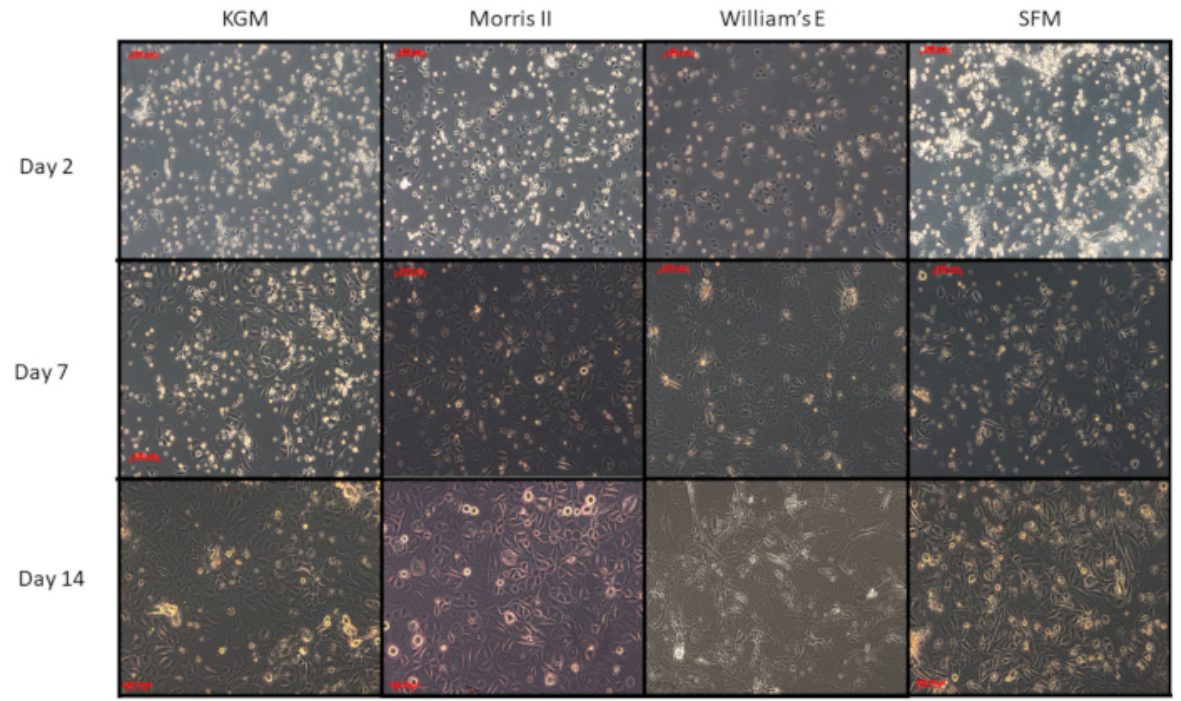

Figure 3: Comparison of four different media on primary cultures of epidermal cells from adult female mice. Primary keratinocytes were isolated from the dorsal mice skin and counted for seeding using four different media (KGM, SFM, Willem's-E and Morris-2). Equal numbers of keratinocytes were seeded and followed for their general morphology and growth pattern. Note that the proliferating keratinocytes have slightly different morphologies. KGM, SFM, and Morris-2 all of which are reduced calcium media have the most robust growth after fourteen days. In contrast, the cells do not persist when cultured in Williams E medium that has $1.4 \mathrm{mM}$ calcium and a high ratio of potassium to sodium. Surprisingly, Williams E medium with supplements and twenty percent fetal bovine serum supports keratinocyte clonal cultures far better than any other medium tested, probably because the enriched Williams E medium helps the 3T3 feeder cells to "feed" better. Please click here to view a larger version of this figure. 


\begin{tabular}{|c|c|}
\hline Solutions and Media & Comments \\
\hline \multicolumn{2}{|l|}{ Harvesting Solutions } \\
\hline \multicolumn{2}{|l|}{$2.5 \% \operatorname{tryp} \sin (5 \mathrm{~mL})$} \\
\hline \multicolumn{2}{|l|}{ Dulbecco's PBS (500 mL) } \\
\hline \multicolumn{2}{|l|}{ Gentamycin (2 mL) } \\
\hline \multicolumn{2}{|l|}{ PBS with 2x gentamycin $(45 \mathrm{~mL})$} \\
\hline \multicolumn{2}{|l|}{ Phosphate-buffered saline (PBS) with 2x gentamycin } \\
\hline \multicolumn{2}{|l|}{ Trypsin solution } \\
\hline \multicolumn{2}{|l|}{ Cell Culture Solutions } \\
\hline \multicolumn{2}{|l|}{ Purecol-fibronectin dish-coating solution: } \\
\hline \multicolumn{2}{|l|}{$1 \mathrm{M}$ HEPES $(1 \mathrm{~mL})$} \\
\hline \multicolumn{2}{|l|}{116 mM CaCl2 (1 mL) } \\
\hline \multicolumn{2}{|l|}{ Bovine serum albumin $1.0 \mathrm{mg} / \mathrm{mL}(10 \mathrm{~mL})$} \\
\hline \multicolumn{2}{|l|}{ Cell culture medium $(100 \mathrm{~mL})$} \\
\hline \multicolumn{2}{|l|}{ Fibronectin (1 mg) } \\
\hline \multicolumn{2}{|l|}{ Purecol collagen (1 mL) } \\
\hline \multicolumn{2}{|l|}{ Cell freezing solution } \\
\hline \multicolumn{2}{|l|}{ DMSO (2 mL) } \\
\hline \multicolumn{2}{|l|}{ DMEM with $10 \%$ BCS and pen-strep } \\
\hline Harvesting Medium & Needs to be without calcium \\
\hline \multicolumn{2}{|l|}{ 2x gentamycin (1 mL) } \\
\hline \multicolumn{2}{|l|}{ FBS $(50 \mathrm{~mL})$} \\
\hline \multicolumn{2}{|l|}{ SMEM (500 mL) } \\
\hline \multicolumn{2}{|l|}{ High-Calcium Williams' E Media with: } \\
\hline \multicolumn{2}{|l|}{ EGF $(5 \mu \mathrm{g} / \mathrm{mL}) 1 \mathrm{~mL}$} \\
\hline \multicolumn{2}{|l|}{ Glutamine $14.5 \mathrm{~mL}$} \\
\hline \multicolumn{2}{|l|}{ Hydrocortisone $(1 \mathrm{mg} / \mathrm{mL}) 0.5 \mathrm{~mL}$} \\
\hline \multicolumn{2}{|l|}{ Insulin $1 \mathrm{~mL}$} \\
\hline \multicolumn{2}{|l|}{ LinoAcid-BSA $(0.1 \mathrm{mg} / \mathrm{mL}) 0.5 \mathrm{~mL}$} \\
\hline MEM Ess AminoAcids $4 \mathrm{~mL}$ & \\
\hline MEM Vitamins $5 \mathrm{~mL}$ & \\
\hline Penicillin-Streptomycin $5 \mathrm{~mL}$ & \\
\hline Transferrin $(5 \mathrm{mg} / \mathrm{mL}) 1 \mathrm{~mL}$ & \\
\hline Vit A $(1 \mathrm{mg} / 1,000 \mu \mathrm{L}) 57.5 \mu \mathrm{L}$ & \\
\hline Vit E $1 \mathrm{mg} / \mathrm{mL}\left(4^{\circ} \mathrm{C}\right) 3.5 \mu \mathrm{L}$ & \\
\hline Vit D2 $(10 \mathrm{mg} / \mathrm{mL}) 50 \mu \mathrm{L}$ & \\
\hline 3T3 fibroblast complete growth medium (CGM) & \\
\hline BCS (100 mL) & \\
\hline DMEM (900 mL) & \\
\hline Penicillin-streptomycin $(10 \mathrm{~mL})$ & \\
\hline KGM & Medium used for mass culture is a reduced calcium medium \\
\hline Morris 2 medium with the same supplements as Williams' E & A reduced calcium variant of Williams E with supplements \\
\hline
\end{tabular}

Table 1: Solution and media recipes. 


\section{Discussion}

The keratinocyte harvesting method described here was developed to produce high yields of highly culturable primary epidermal keratinocytes from the back of adult female mice. These keratinocytes are suitable for flow cytometry, molecular biology application, and primary cell culture, including the clonogenic assay reported here. This keratinocyte harvesting method also has been useful for studying other downstream aspects of cutaneous chemical carcinogenesis and tumor promotion ${ }^{1,13}$.

There are several critical steps in the protocol. First, for rigor and reproducibility, female mice of age $54 \pm 2$ days were used. This has enabled us to perform sensitive and quantitative colony assays from multiple strains of mice and to use them as a phenotype in linkage analysis leading to identification of least one new stem cell regulatory gene ${ }^{10,11}$. Second, it is helpful to cut the skins into smaller pieces, as the trypsinization is more effective than trying to keep the skin whole. Third, the time and the temperature of the trypsin flotation is very important to the subsequent culturability. Moreover, one needs to "poke considerably" at the hairs remaining on the filter to dislodge the attached cells. This step is important to obtain high yields of cells. Furthermore, the $32{ }^{\circ} \mathrm{C}$ temperature of the incubator is important for the longer-term cultivation of keratinocytes from adult mice. Finally, in this protocol, the parallel readouts of in vitro and in vivo experiments ${ }^{1}$ are based on primary cultures rather than subcultures or cell lines. Notably, if harvesting primary keratinocytes for the first time using this protocol, keep the remaining dermis after scraping to confirm the full removal of hair follicles along with epidermis by histopathological observation.

The principal strength of this protocol for harvesting adult mouse keratinocytes is that it produces high yields of culturable cells that are suitable for many downstream applications. The chief limitation is that some cell surface epitopes may be sensitive to trypsinization such that immunostaining may be compromised. Therefore, when testing a new cell surface antibody, it may be prudent to use a dispase ${ }^{6}$ or thermolysin ${ }^{5}$ based method for harvesting for comparison. The significance of this protocol is that it has been rigorously tested, quantified, and applied to such diverse applications as assays for clonogenic stem cells ${ }^{1,9,10,11}$, for mass cultures in biochemistry ${ }^{8}$, for FACS sorting in stem cell analysis ${ }^{3,4}$, for molecular biology $y^{3,12}$, and for ongoing RNA and DNA sequencing.

\section{Disclosures}

The authors have nothing to disclose.

\section{Acknowledgments}

The authors have no acknowledgments.

\section{References}

1. Morris, R. J., Tacker, K. C., Fischer, S. M., Slaga, T. J. Quantitation of primary in vitro clonogenic keratinocytes from normal adult murine epidermis, following initiation, and during promotion of epidermal tumors. Cancer Research. 48 (22), 6285-6290 (1988).

2. Tani, H., Morris, R. J., Kaur, P. Enrichment for murine keratinocyte stem cells based on cell surface phenotype. Proceedings of the National Academy of Sciences of the United States of America. 97 (20), 10960-10965 (2000).

3. Morris, R. J. et al. Capturing and profiling adult hair follicle stem cells. Nature Biotechnology. 22 (4), 411-417 (2004).

4. Trempus, C. S. et al. Enrichment for living murine keratinocytes from the hair follicle bulge with the cell surface marker CD34. Journal of Investigative Dermatology. 120 (4), 501-511 (2003).

5. Redvers, R. P.. Kaur, P. Serial cultivation of primary adult murine keratinocytes. Methods in Molecular Biology. 289, 15-22 (2005).

6. Jensen, K. B., Driskell, R. R.. Watt, F. M. Assaying proliferation and differentiation capacity of stem cells using disaggregated adult mouse epidermis. Nature Protocols. 5 (5), 898-911 (2010).

7. Blacker, K. L., Williams, M. L.. Goldyne, M. Mitomycin C-treated 3 T3 fibroblasts used as feeder layers for human keratinocyte culture retain the capacity to generate eicosanoids. Journal of Investigative Dermatology. 89 (6), 536-539 (1987).

8. Morris, R. J. Procedure for harvesting epidermal cells from the dorsal epidermis of adult mice for primary cell culture in "high calcium" defined medium. Cambridge University Press. (1994).

9. Wu, W. Y.. Morris, R. J. Method for the harvest and assay of in vitro clonogenic keratinocytes stem cells from mice. Methods in Molecular Biology. 289 79-86 (2005).

10. Popova, N. V., Teti, K. A., Wu, K. Q.. Morris, R. J. Identification of two keratinocyte stem cell regulatory loci implicated in skin carcinogenesis. Carcinogenesis. 24 (3), 417-425 (2003).

11. Popova, N. V., Tryson, K. A., Wu, K. Q.. Morris, R. J. Evidence that the keratinocyte colony number is genetically controlled. Experimental Dermatology. 11 (6), 503-508 (2002).

12. Trempus, C. S. et al. Comprehensive microarray transcriptome profiling of CD34-enriched mouse keratinocyte stem cells. Journal of Investigative Dermatology. 127 (12), 2904-2907 (2007).

13. Baer-Dubowska, W., Morris, R. J., Gill, R. D.. DiGiovanni, J. Distribution of covalent DNA adducts in mouse epidermal subpopulations after topical application of benzo(a)pyrene and 7,12-dimethylbenz(a)anthracene. Cancer Research. 50 (10), 3048-3054 (1990).

14. Blanpain, C., Lowry, W. E., Geoghegan, A., Polak, L.. Fuchs, E. Self-renewal, multipotency, and the existence of two cell populations within an epithelial stem cell niche. Cell. 118 (5), 635-648 (2004). 